\title{
Clinical manifestations in patients with musculoskeletal pain post-chikungunya
}

\author{
Manifestações clínicas em pacientes com dores musculoesqueléticas pós-chikungunya
}

Ben-Hur James Maciel de-Araujo', Patricia Bueno Nestarez Hazime², Francisca Joyce Vasconcelos Galeno¹, Laís Nascimento Candeira $^{1}$, Mayare Fortes Sampaio', Fuad Ahmad Hazime ${ }^{3}$

DOI 10.5935/2595-0118.20190060

\section{ABSTRACT}

BACKGROUND AND OBJECTIVES: Chronic clinical manifestations of the chikungunya virus infection are associated with high rates of disability and worsening of quality of life, representing one of the major challenges for global public health. The objective of this study was to investigate the clinical-psycho-functional presentation of the chikungunya virus-infected individuals with complaints of chronic musculoskeletal pain.

METHODS: Twenty-two individuals with a diagnosis of chikungunya virus infection and a complaint of persistent musculoskeletal pain ( $\geq 3$ months) participated in the study. The clinical-psycho-functional evaluation was performed through the intensity and affective-emotional aspect of pain, quality of life, kinesophobia, global perception of post-infection pain recovery and emotional functionality. In the end, the pressure pain threshold and the conditioned pain modulation were evaluated. RESULTS: The clinical presentation of pain revealed long persistence 17.5 \pm 7.4 months; predominant in the lower limbs (45.5\%); mean intensity $(5.5 \pm 2.1)$; mild to moderate affective-emotional changes; moderate kinesophobia $(46 \pm 6.5)$ and low overall perception of improvement $(1.5 \pm 2.5)$. The Beck Depression Inventory and the visual analog scale for anxiety showed little change. Quality of life presented mild to moderate impairment, and pain modulation showed a slight increase in the pressure pain threshold (6.3\%).

\footnotetext{
Ben-Hur James Maciel de-Araujo - (Dhttps://orcid.org/0000-0003-2414-8571; Patricia Bueno Nestarez Hazime - (Dhttps://orcid.org/0000-0002-4287-6540;

Francisca Joyce Vasconcelos Galeno - (Dhttps://orcid.org/0000-0002-5824-5524;

Laís Nascimento Candeira - (Dhttps://orcid.org/0000-0002-7744-3526;

Mayare Fortes Sampaio - (Dhttps://orcid.org/0000-0002-4665-6369;

Fuad Ahmad Hazime - (Dhttps://orcid.org/0000-0001-7729-1203.

1. Universidade Federal do Piauí, Departamento de Fisioterapia, Parnaíba, PI, Brasil.

2. Prefeitura de Taboão da Serra, Serviço de Assistência Especializada DST/AIDS, Taboão

da Serra, SP, Brasil.

3. Universidade Federal do Piauí, Programa de Pós-Graduação em Ciências Biomédicas, Parnaíba, PI, Brasil.
}

Submitted on June 03, 2019.

Accepted for publication on September 23, 2019.

Conflict of interests: none - Sponsoring sources: none.

Correspondence to:

Departamento de Fisioterapia, Universidade Federal do Piauí

Campus de Parnaíba

Avenida São Sebastião, 2819 - Bairro Nossa Senhora de Fátima

64202-020 Parnaíba, PI, Brasil.

E-mail: fuad@ufpi.edu.br

(C) Sociedade Brasileira para o Estudo da Dor
CONCLUSION: The chronic phase of the chikungunya virus infection is characterized by persistent moderate-intensity pain, both in sensory and affective levels, with moderate kinesophobia, worsening of quality of life, perception of poor post-infection recovery, and a decrease in the pain descending inhibitory pathways.

Keywords: Chikungunya virus, Chronic pain, Clinical evolution, Signals and symptoms.

\section{RESUMO}

JUSTIFICATIVA E OBJETIVOS: As manifestaçōes clínicas crônicas da infecção pelo vírus chikungunya estão associadas a altos índices de incapacidade e piora da qualidade de vida, representando um dos grandes desafios para a saúde pública mundial. O objetivo deste estudo foi investigar a apresentação clínica-psico-funcional de indivíduos infectados pelo vírus chikungunya com queixas de dores musculoesqueléticas crônicas.

MÉTODOS: Participaram do estudo 22 indivíduos com diagnóstico de infecção pelo vírus chikungunya e queixa de dor musculoesquelética persistente ( $\geq 3$ meses). A avaliação clínica-psico-funcional foi realizada por meio da intensidade e aspecto afetivo-emocional da dor, qualidade de vida, cinesiofobia, percepção global de recuperaçáo da dor pós-infecção e funcionalidade emocional. Ao final foi avaliado o limiar de dor por pressão e a modulaçáo condicionada da dor.

RESULTADOS: A apresentação clínica da dor revelou longa persistência, 17,5 \pm , 4 meses; predominância nos membros inferiores $(45,5 \%)$; intensidade média $(5,5 \pm 2,1)$; alteraçóes afetiva-emocionais leves a moderadas; moderada cinesiofobia $(46 \pm 6,5)$ e baixa percepção global de melhora $(1,5 \pm 2,5)$. O Inventário de Depressão de Beck e a escala analógica visual para ansiedade apresentaram pouca alteraçáo. A qualidade de vida apresentou prejuízos leves a moderados, e a modulaçáo da dor revelou pouco aumento do limiar de dor por pressão $(6,3 \%)$.

CONCLUSÁO: A fase crônica da infecção pelo vírus chikungunya tem como apresentaçấo clínica dor persistente de moderada intensidade, em nível sensorial e afetivo, além de moderada cinesiofobia, piora na qualidade de vida, percepçáo de pouca recuperação pós-infecção e diminuição da ativação inibitória descendente da dor.

Descritores: Dor crônica, Evolução clínica, Sinais e sintomas, Vírus chikungunya.

\section{INTRODUCTION}

Chikungunya is an arboviral disease of the Togaravidae family transmitted by the bite of the mosquito of the species Aedes, Ae. 
Aegypti and Ae. Albopictus' ${ }^{1}$. Since the first outbreak of chikungunya reported in Tanzania in mid- $1953^{2}$, there has been an increase in infection in Asian ${ }^{3,4}$ and African ${ }^{5,6}$ countries. In Brazil, the first indigenous cases were confirmed in Oiapoque (AP) in 20147. Since then, there has been a significant increase in confirmed notifications in all states of the country, either by laboratory or clinical criteria.

The main clinical manifestations in the acute phase are similar to those of dengue: high fever, headache, chills, nausea, vomiting, fatigue, back pain, myalgia, and arthralgia ${ }^{8}$. The acute or febrile phase lasts until the $14^{\text {th }}$ day, but in some cases, there is a persistence of symptoms such as joint pain for up to three months, characterized as the sub-acute phase. When complaints of musculoskeletal pain persist for more than three months, the chronic phase sets in?. The mechanisms involved in the chronic characteristic of musculoskeletal pain are not fully understood, but some risk factors have been pointed out: genetic predisposition; pre-existing arthropathy or other comorbidities; tissue damage induced directly by the virus; long-term persistence of chikungunya infection in tissues with inflammation and activation of autoimmune responses ${ }^{10}$. Besides complaints of musculoskeletal pain, the chronic phase is associated with a physical disability and worsening of quality of life ${ }^{11,12}$.

Although current treatments have some results for symptom relief $^{13}$, clinical manifestations of this chronic characteristic may still be present years after the infection ${ }^{14}$. In this context, the clinical-functional assessment of the disease is extremely important for the planning of effective prevention and treatment strategies.

This study aimed to investigate the clinical-psycho-functional presentation of patients infected with the chikungunya virus complaining about chronic musculoskeletal pain.

\section{METHODS}

This is a cross-sectional, descriptive, and exploratory study, conducted from January 2018 to June 2019. Individuals with a medical diagnosis of chikungunya and complaints of post-infection musculoskeletal pain were recruited through social networks and printed communication in public and private health services in the city of Parnaíba-PI. The sample size calculation considered the number of probable cases reported $(\mathrm{n}=825)$, according to the $52^{\text {nd }}$ Epidemiological Week Bulletin (2017) released by the Piauí State Government, and the population of the city of Parnaíba $(n=137,485)$. Adopting a confidence interval and a precision value of $95 \%$ and \pm 0.07 , respectively, the minimum sample size was estimated in 41 subjects.

The inclusion criteria were: 1) confirmed medical diagnosis of chikungunya virus infection; 2 ) both genders; 3 ) persistent complaint of musculoskeletal pain (symptoms $\geq 3$ months). Participants with pain complaints related to previous diseases, such as inflammatory rheumatic disease, musculoskeletal lesions, neurological diseases, or diabetic neuropathy, were excluded.

After fulfilling the inclusion criteria, participants answered an unstructured questionnaire containing personal data and anthropometric characteristics. Then, the intensity and affective-sensation aspect of pain, quality of life, kinesophobia, the overall perception of pain recovery after infection, and emotional functionality were evaluated. In the end, the pressure pain threshold and the conditioned pain modulation were assessed. Pain intensity was assessed using an 11-point numerical scale (zero-10), with zero being considered no pain and 10 the worst possible pain $^{15}$. The sensory and affective aspect of pain were verified by the McGill questionnaire, short version (SF-MPQ) containing 15 pain sensation descriptors (11 sensory and 4 affective), with each descriptor classified on a 4-point scale, zero $=$ none, $15=$ mild, $25=$ moderate, and $35=$ intense $^{16}$.

The quality of life was assessed using the EQ-5D questionnaire, which covers five health domains: mobility, personal care, everyday activities, pain/malaise, anxiety/depression. This questionnaire also includes a visual analog scale (VAS), where zero indicates the worst imaginable state of health, and 100 indicates the best imaginable state of health ${ }^{17}$.

Kinesophobia was assessed using the Tampa Scale for Kinesophobia. This scale contains 17 items that seek to measure excessive fear or aversion to movement and physical activity. Each item has four answer options: strongly disagree (1 point), partially disagree (2 points), partially agree (3 points), and fully agree (4 points). The sum of the items answered may indicate lower (17 points) or higher kinesophobia (68 points) $)^{15}$. The overall perception of recovery after the infection was assessed by the numerical global perception scale (GPS). This scale contains 11 points, ranging from -5 to +5 , where -5 is the perception of being extremely worse, zero: no modification, and +5 the perception of being fully recovered ${ }^{15}$.

The pain threshold was assessed with the manual pressure algometer (FORCE TEN FDX, USA). The algometer tip, about $1 \mathrm{~cm}^{2}$ thick, was applied perpendicular to the skin surface on the dominant arm over the tendon of the extensor carpi radiallis brevis muscle, $2 \mathrm{~cm}$ distal to the lateral epicondyle. Three measurements were taken, and in each test, participants were instructed to respond "stop" to the first pain sensation caused by the mechanical stimulation of the algometer ${ }^{18}$.

Conditioned pain modulation (CPM) was assessed by the tissue cooling test ${ }^{19}$. Participants remained seated with the dominant forearm over a support, and the contralateral forearm immersed in a bucket of ice and water at $10^{\circ} \mathrm{C}$ (conditioning stimulus). The pressure pain threshold (PPT) (test stimulus) was measured during four intervals: (1) before immersion, (2) after 30 seconds of immersion, (3) after $1 \mathrm{~min} 30$ s of immersion, and (4) 1 minute after withdrawing the immersed hand from the cooling system. The CPM was estimated by the difference in the PPT between the baseline condition (pre-immersion) and post-immersion conditions ${ }^{18}$.

Symptoms of anxiety and depression were assessed by the Brazilian version of the Beck Depression Inventory (BDI) and the VAS for anxiety, respectively. The BDI is a self-rated measure of depression that uses a 21-item questionnaire, the intensity of which ranges from zero to 3 (higher scores indicate more depressive symptoms ${ }^{20}$. The VAS for general anxiety is assessed by a $100 \mathrm{~mm}$ long horizontal line. The far-left end means no anxiety, and the far-right end means the worst possible anxiety ${ }^{21}$.

The study was approved by the Ethics Committee of the Federal University of Piauí (UFPI) under №. 2,883,331/2018. All participants signed the Free Informed Consent Form (FICT). 


\section{Statistical analysis}

The data were input in the Microsoft Excel software version 2010 for Windows. The descriptive analyses of the investigated variables were performed through means, frequencies (absolute and relative), and standard deviations. All data were analyzed using the IBM SPSS software v.20 for Windows.

\section{RESULTS}

Forty-nine individuals were recruited for clinical evaluation. However, 27 individuals were excluded because they no longer complained of pain $(n=8)$; no medical diagnosis $(n=9)$ and 10 subjects refused to participate in the study. Twenty-two individuals $(86.4 \%$ female) with a medical diagnosis of chikungunya virus infection participated in the study. The mean $( \pm S D)$ age, weight, height and body mass index (BMI) were 46.4 years (12.0), $63.3 \mathrm{~kg}(17.5), 1.6 \mathrm{~m}(0.1)$ and $26.1 \mathrm{~kg} / \mathrm{m}^{2}(4.4)$, respectively. The predominant level of education was high school $(31.8 \%)$ and primary $(31.8 \%)$, followed by college education $(27.3 \%)$ and no education (9\%). Most participants did not practice physical activity $(59.1 \%)$, and all denied smoking. The mean period of pain was 17.5 months (7.4), and the areas of major complaints were the lower limbs (45.5\%), lower limbs and upper limbs (45.5\%), and upper limbs $(9.1 \%)$. The clinical characteristics, quality of life and conditioned pain modulation are described in tables 1 , 2 , and 3 , respectively.

Table 1. Participants' clinical characteristics

\begin{tabular}{lcc}
\hline & Mean & Standard deviation \\
\hline Pain intensity (0-10) & 5.5 & 2.1 \\
PRI-T (0-45) & 17.3 & 8.4 \\
PRI-S (0-33) & 12.2 & 5.5 \\
PRI-A (0-12) & 5.1 & 3.3 \\
Kinesophobia (17-68). & 43.6 & 6.5 \\
Overall perception (-5 to +5) & 1.5 & 2.5 \\
Depression (0-63) & 10.9 & 5.9 \\
Anxiety (0-100) & 3.1 & 2.4 \\
\hline
\end{tabular}

$\overline{\mathrm{PRI}-\mathrm{T}}=$ total pain index, $\mathrm{PRI}-\mathrm{S}=$ sensory aspect of pain, $\mathrm{PRI}-\mathrm{A}=$ affective aspect of pain; Kinesophobia = assessed by the Tampa Scale for Kinesophobia. High scores on intensity, pain sensory aspect, and kinesophobia indicate worsening of pain and aversion to movement or physical activity. Overall perception assessed by the overall effect perception scale. Low scores indicate a worsening overall effect.

Table 2. Participants' quality of life

\begin{tabular}{lcc}
\hline EQ-5D Domains & Levels & $\mathrm{n}(\%)$ \\
\hline \multirow{3}{*}{ Mobility } & 1 & $7(31.8)$ \\
& 2 & $5(22.7)$ \\
& 3 & $10(45.5)$ \\
& 4 & - \\
& 5 & - \\
& 1 & $14(63.6)$ \\
\hline
\end{tabular}

Table 2. Participants' quality of life - continuation

\begin{tabular}{|c|c|c|}
\hline EQ-5D Domains & Levels & n (\%) \\
\hline \multirow[t]{5}{*}{ Personal care } & 2 & $1(4.5)$ \\
\hline & 3 & 7(31.8) \\
\hline & 4 & - \\
\hline & 5 & - \\
\hline & 1 & $8(36.4)$ \\
\hline \multirow[t]{5}{*}{ Common activities } & 2 & $7(31.8)$ \\
\hline & 3 & $6(27.3)$ \\
\hline & 4 & $1(4.5)$ \\
\hline & 5 & - \\
\hline & 1 & - \\
\hline \multirow[t]{5}{*}{ Pain/discomfort } & 2 & $10(45.5)$ \\
\hline & 3 & $11(55)$ \\
\hline & 4 & $1(4.5)$ \\
\hline & 5 & - \\
\hline & 1 & $8(36.4)$ \\
\hline \multirow[t]{4}{*}{ Anxiety/depression } & 2 & $7(31.8)$ \\
\hline & 3 & $7(31.8)$ \\
\hline & 4 & - \\
\hline & 5 & - \\
\hline
\end{tabular}

$\mathrm{EQ}-5 \mathrm{D}=$ EuroQol quality of life questionnaire with five dimensions. Level $1=\mathrm{no}$ problem; Level 2 = mild problem; Level $3=$ moderate problem; Level $4=$ serious problem; Level 5 = Disable.

Table 3. Conditioned Pain Modulation

\begin{tabular}{lccc}
\hline $\begin{array}{l}\text { Pressure pain threshold } \\
\text { (Test stimulus) }\end{array}$ & $\begin{array}{c}\text { Pre } \\
(\mathrm{kgf})\end{array}$ & $\begin{array}{c}\text { Post } \\
(\mathrm{kgf})\end{array}$ & $\begin{array}{c}\text { CPM } \\
(\%)\end{array}$ \\
\hline Baseline & $3.2(0.9)$ & - & - \\
30s immersion & - & $3.4(1.0)$ & 6.3 \\
1.5min immersion & - & $3.4(1.0)$ & 6.3 \\
1 min post/immersion & - & $3.2(0.9)$ & 0 \\
\hline
\end{tabular}

$\mathrm{CPM}=$ conditioned pain modulation kilogram-force values (Kgf) expressed as mean and standard deviation.

\section{DISCUSSION}

Data analysis showed that infection with the chikungunya virus leads to persistent pain, with temporal characteristics of chronicity and medium to high-intensity magnitudes. The sensory and affective aspects of pain ranged from mild to moderate. Although symptoms of depression and anxiety have not been previously assessed, nor have they included inclusion/exclusion criteria, overall participants did not have clinically relevant changes in symptoms of depression [(10.9 \pm 5.9$)$ score of $0-63]$ and anxiety [(3.1 \pm 2.4$)$ score of $0-100]$. On the other hand, the depression and anxiety domains, assessed by the EQ-5D quality of life questionnaire, showed that these psychiatric morbidities were present in mild to moderate magnitudes. There are few reports in the literature on psychiatric morbidities associated with chikungunya, which makes it difficult to compare with the current results. A preliminary Indian study found the presence of psychiatric mor- 
bidity in 20 infected individuals, mainly in the form of episodes of depression $(\mathrm{n}=5)$ and anxiety disorders $(\mathrm{n}=3)^{22}$.

Despite the differences in the assessment of depression and anxiety symptoms, a moderate level of kinesophobia was observed, indicating that complaints of persistent pain may induce a higher perception of excessive fear or aversion to movement and physical activity. However, as it is a single assessment, it is possible that these changes were already present before the clinical evaluation. In the context of physical rehabilitation, the presence of kinesophobia may indicate a poor prognosis or greater difficulty in adhering to treatment through exercise. In these cases, it is possible that strategies for a reconception of beliefs and changing attitudes, such as cognitive-behavioral ${ }^{23}$ therapy, may decrease kinesophobia and increase the chances that patients will benefit from the hypoalgesic effect of therapeutic exercise $e^{24,25}$.

The quality of life assessment showed that most participants had mild harm (level 2, score 1 to 5) to moderate (level 3, score 1 to 5). Regarding the domains of health, pain, and/ or malaise and mobility, they were considered a moderate problem in 55 and $45 \%$ of participants, respectively. There were also harms in the domains of personal care (moderate) and everyday activities (mild). Harms on post-infection quality of life may be related to the maintenance or exacerbation of pain complaints ${ }^{11}$, where the time factor of infection is directly related to increased pain symptoms and loss of functional capacity ${ }^{26}$. When compared to the initial period of symptoms, participants reported overall perception of poor recovery after infection [(1.5 \pm 2.5$)-5$ to +5 score], showing that chikungunya may negatively impact the health of patients in the long term ${ }^{11}$.

The CPM assessment showed little increase (6.3\%) in the pressure pain threshold during the conditioning stimulus (cold water) in relation to the baseline condition. This result suggests little activation of the descending pain inhibitory pathway, indicating that the chronic phase of the chikungunya virus infection negatively interferes with the endogenous capacity for analgesia. The assessment of the dysfunction of the endogenous pain modulatory mechanisms, present in various chronic pain conditions ${ }^{27}$, may provide important information to guide more effective prevention and treatment strategies. For example, failure of CPM during the pre-operative phase is associated with a higher likelihood of chronic post-operative pain ${ }^{28.29}$. Concerning treatment, therapeutic strategies that activate pain inhibitory mechanisms similar to CPM, such as exercises ${ }^{30}$ or noninvasive neuromodulation techniques ${ }^{31}$, maybe one of the ways for chronic pain relief.

The main limitation of this study refers to the sample size. Although a broad recruitment strategy has been used, the state of Piauí has shown significant reductions in new cases. According to the Bulletin of the $3^{\text {rd }}$ Epidemiological Week -2019 , there was a $95.6 \%$ reduction in incidence compared to the same period of 2018. Other limitations may also have influenced the results found: (1) Confounding variables, such as previous symptoms of depression, anxiety, and kinesophobia; and (2) Method used for the evaluation of CPM.

\section{CONCLUSION}

The clinical presentation of the chronic phase of the chikungunya virus infection is persistent pain of moderate intensity in sensory and affective level, moderate kinesophobia, decrease in the quality of life, perception of poor recovery after infection, and decrease in the activation of the pain descending inhibitory pathways.

\section{REFERENCES}

1. Pialoux G, Gaüzère BA, Jauréguiberry $S$, Strobel M. Chikungunya, an epidemic arbovirosis. Lancet Infect Dis. 2007;7(5):319-27.

2. Ross RW. The Newala epidemic. III. The virus: isolation, pathogenic properties and relationship to the epidemic. J Hyg. 1956;54(2):177-91.

3. Dash PK, Parida MM, Santhosh SR, Verma SK, Tripathi NK, Ambuj S, et al. East Central South African genotype as the causative agent in reemergence of Chikungunya outbreak in India. Vector Borne Zoonotic Dis. 2007;7(4):519-27.

4. Harapan H, Michie A, Mudatsir M, Nusa R, Yohan B, Wagner AL, et al. Chikungunya virus infection in Indonesia: a systematic review and evolutionary analysis. BMC Infect Dis. 2019;19(1):243.

5. Gérardin P, Guernier V, Perrau J, Fianu A, Le Roux K, Grivard P, et al. Estimating Chikungunya prevalence in La Réunion Island outbreak by serosurveys: two methods for two critical times of the epidemic. BMC Infect Dis. 2008;8:99.

6. Simo FBN, Bigna JJ, Well EA, Kenmoe S, Sado FBY, Weaver SC, et al. Chikungunya virus infection prevalence in Africa: a contemporaneous systematic review and meta-analysis. Public Health. 2019;166:79-88.

7. Ministério da Saúde. Boletim Epidemiológico. Secretaria de Vigilância em Saúde. 2014. 1-6p.

8. Castro AP, Lima RA, Nascimento JS. Chikungunya: vision of the pain clinician. Rev Dor. 2016;17(4):299-302.

9. Brasil, M.d.S., Chikungunya: Manejo Clínico, S.d.V.e.S.S.d.A. Básica, Brasilia, Editor; $2017.78 \mathrm{p}$

10. McCarthy MK, Morrison TE. Chronic chikungunya virus musculoskeletal disease: what are the underlying mechanisms? Future Microbiol. 2016;11(3):331-4.

11. Soumahoro MK, Gérardin P, Boëlle PY, Perrau J, Fianu A, Pouchot J, et al. Impact of Chikungunya virus infection on health status and quality of life: a retrospective cohort study. PLoS One. 2009; 4(11):e7800.

12. Couturier E, Guillemin F, Mura M, Léon L, Virion JM, Letort MJ, et al. Impaired quality of life after chikungunya virus infection: a 2-year follow-up study. Rheumatology. 2012;51(7):1315-22.

13. Sales GM, Barbosa IC, Canejo Neta LM, Pelo PL, Leitão RA, Melo HMA. Treatment of chikungunya chronic arthritis: a systematic review. Rev Assoc Med Bras. 2018;64(1):63-70.

14. Marimoutou C, Ferraro J, Javelle E, Deparis X, Simon F. Chikungunya infection self-reported rheumatic morbidity and impaired quality of life persist 6 years later. Clin Microbiol Infect. 2015;21(7):688-93.

15. de Souza FS, Marinho Cda S, Siqueira FB, Maher CG, Costa LO. Psychometric testing confirms that the Brazilian-Portuguese adaptations, the original versions of the Fear-Avoidance Beliefs Questionnaire, and the Tampa Scale of Kinesiophobia have similar measurement properties. Spine. 2008;33(9):1028-33.

16. Menezes Costa Lda C, Maher CG, McAuley JH, Hancock MJ, de Melo Oliveira W, Azevedo DC. et al., The Brazilian-Portuguese versions of the McGill Pain Questionnaire were reproducible, valid, and responsive in patients with musculoskeletal pain. J Clin Epidemiol. 2011;64(8):903-12.

17. EuroQol-Group. EQ-5D: a standardised instrument for use a measure of health outcome EQ-5D translations. 2010 [cited 2019 March, 26]; Available from: www.euroqol.org.

18. Shiro Y, Ikemoto T, Terasawa Y, Arai YP, Hayashi K, Ushida T, et al. Physical activity may be associated with conditioned pain modulation in women but not men among healthy individuals. Pain Res Manag. 2017;2017:9059140.

19. Knudsen L, Drummond PD. Cold-induced limb pain decreases sensitivity to pressure-pain sensations in the ipsilateral forehead. Eur J Pain. 2009;13(10):1023-9.

20. Gorenstein C, Andrade L, Vieira Filho AH, Tung TC, Artes R. Psychometric properties of the Portuguese version of the Beck Depression Inventory on Brazilian college students. J Clin Psychol. 1999;55(5):553-62.

21. Williams VS, Morlock RJ, Feltner D. Psychometric evaluation of a visual analog scale for the assessment of anxiety. Health Qual Life Outcomes. 2010;8:57.

22. Bhatia MS, Gautam P, Jhanjee A. Psychiatric morbidity in patients with chikungunya fever: first report from India. J Clin Diagn Res. 2015;9(10):VC01-VC03.

23. Hofmann SG, Asnaani A, Vonk IJ, Sawyer AT, Fang A. The efficacy of cognitive behavioral therapy: a review of meta-analyses. Cognit Ther Res. 2012;36(5):427-40.

24. Naugle KM, Fillingim RB. Riley JL 3rd. A meta-analytic review of the hypoalgesic effects of exercise. J Pain. 2012;13(12):1139-50.

25. Polaski AM, Phelps AL, Kostek MC, Szucs KA, Kolber BJ. Exercise-induced hypoalgesia: a meta-analysis of exercise dosing for the treatment of chronic pain. PLoS One. 2019;14(1):e0210418. 
26. de Souza CG, da Costa JF, de Sousa Dantas D, de Abreu Freitas RP, Lopes JM, et al. Evaluation of pain, functional capacity and kinesiophobia in women in the chronic stage of chikungunya virus infection: a cross-sectional study in northeastern Brazil. Acta Trop. 2018;199:104853. [Epub ahead of print].

27. Lewis GN, Rice DA, McNair PJ. Conditioned pain modulation in populations with chronic pain: a systematic review and meta-analysis. J Pain. 2012;13(10):936-44.

28. Yarnitsky D, Crispel Y, Eisenberg E, Granovsky Y, Ben-Nun A, Sprecher E, et al. Prediction of chronic post-operative pain: pre-operative DNIC testing identifies patients at risk. Pain. 2008;138(1):22-8.
29. Wilder-Smith OH, Schreyer T, Scheffer GJ, Arendt-Nielsen L. Patients with chronic pain after abdominal surgery show less preoperative endogenous pain inhibition and more postoperative hyperalgesia: a pilot study. J Pain Palliat Care Pharmacother. 2010;24(2):119-28.

30. Vaegter HB, Handberg G, Graven-Nielsen T. Similarities between exercise-induced hypoalgesia and conditioned pain modulation in humans. Pain. 2014;155(1):158-67.

31. O'Connell NE, Marston L, Spencer S, DeSouza LH, Wand BM. Non-invasive brain stimulation techniques for chronic pain. Cochrane Database Syst Rev. 2018;3:CD008208. 